\title{
The resilience of Chinese minorities: Transformation of Chinese entrepreneurs in Lasem batik industry, Central Java, Indonesia
}

\author{
Yesi Mekarsari ${ }^{1}$, Mochamad Iqbal Jatmiko \\ 1,2 Department of Sociology, Universitas Gadjah Mada, Indonesia \\ ${ }^{2}$ Institute for Multiculturalism and Pluralism Studies, Indonesia \\ *Corresponding author \\ E-mail address: yesimekarsari@gmail.com \\ DOI: https://doi.org/10.21107/sml.v3i2.7366
}

\begin{tabular}{|c|c|}
\hline Article Info & Abstract \\
\hline $\begin{array}{l}\text { Keywords: } \\
\text { Social change } \\
\text { Batik } \\
\text { Acculturation } \\
\text { Chinese } \\
\text { businessman } \\
\text { Lasem }\end{array}$ & $\begin{array}{l}\text { The Lasem batik industry underwent a significant dynamic change after } \\
\text { the inauguration of batik as an intangible cultural heritage by UNESCO on } \\
\text { October 2,2009. The increasing growth of the batik industry in Lasem turned } \\
\text { out to affect the decline in industrial ownership by Chinese-Indonesian } \\
\text { business person. Although the Chinese-Indonesian business person served } \\
\text { as an initiator in the Lasem batik industry, it does not guarantee their } \\
\text { survival against a massive ownership transition. This article explores the } \\
\text { changing dynamics of the Lasem batik industry from the perspective of } \\
\text { the Chinese-Indonesian business person who still maintains the continuity } \\
\text { of their business. Employing a qualitative method and a narrative study } \\
\text { approach, this article seeks to deepen the historical narrative about the lives } \\
\text { of six Chinese-Indonesian business persons in the Lasem batik industry. } \\
\text { The findings show that since post-reformation until now, the ownership of } \\
\text { the Lasem batik industry by Chinese-Indonesian business person continues } \\
\text { to decline. Therefore, the expansion of the intra-ethnic network, identity } \\
\text { hybridization, cultural acculturation, and authentication of batik motifs } \\
\text { became the survival strategies of Chinese-Indonesian business persons to be } \\
\text { resistant to industrial ownership transitions and survived competing in the } \\
\text { Lasem batik business. }\end{array}$ \\
\hline
\end{tabular}

Citation suggestion:

Mekarsari, Y., \& Jatmiko, M. I. (2020). The resilience of Chinese minorities: Transformation of Chinese entrepreneurs in Lasem batik industry, Central Java, Indonesia. Simulacra, 3(2), 179-196. https://doi.org/10.21107/ sml.v3i2.7366

Received 29 May 2020; Received in revised form 28 September 2020; Accepted 5 October 2020; Published online 25 November 2020. 


\section{Introduction}

Since batik was inaugurated as a cultural heritage by UNESCO on October 2, 2009, the enthusiasm and demand for batik have continued to grow. The home batik industry was also experiencing rapid development in several regions of Indonesia, especially in Java (Krisnawati et al., 2019). One of the areas that produce high-quality hand-drawn batik with iconic characteristics was Lasem District, Rembang Regency, Central Java. Unlike the batik in Pekalongan, Surakarta, and Yogyakarta, Lasem's hand-drawn batik applies more symbols from the combination of two cultural values, namely Javanese and Chinese (Kurnia \& Windarti, 2019; Lukman et al., 2019).

The uniqueness of Lasem batik has caused market demand to increase, resulting in a surge in the number of Lasem batik industry. Based on data from the Indonesian Pluralism Institute, it was estimated that in 1950 there were 140 Lasem batik industries, while in 2006, the number of batik industries in Lasem decreased drastically to only 20 active industries. However, in 2016, this number again increased to 120 industries (Maulany and Masruroh, 2017:9). In addition to massive promotion, the increase in Lasem's batik industry was also influenced by the realization of local government regulations regarding the use of batik uniforms from Tuesday to Friday, thus helping Lasem batik entrepreneurs to open their business again.

However, the significant increase in the number of Lasem batik industries has also resulted in massive socio-economic changes. Javanese entrepreneurs were now replacing the ownership of the Lasem batik industry, which was previously dominated by Chinese entrepreneurs. The Chinese community who acted as the initiator of the batik industry in the Lasem area experienced a degradation in business ownership. This fact was in accordance with the research by Maulany and Masruroh (2017: 8) which revealed that the number of Lasem batik entrepreneurs from the Chinese group, which was estimated to have reached 20 entrepreneurs in 2006, had decreased to 15 in 2013.

The decline in ownership of the batik industry also changed the social, cultural and economic dynamics for Chinese entrepreneurs who were still involved in the production of Lasem batik to this day. Previous studies were limited to topics such as the revival of the Lasem batik industry based on inter-group harmonization, the entrepreneurship strategy to develop the Lasem batik industry, and the meaning of Lasem batik pattern (Kurnia \& Windarti, 2019; Lukman et al., 2019; Maulany \& Masruroh, 2017; Setyoningrum et al., 2019). On the other hand, the current article focused more on the resilience of Chinese entrepreneurs who were still involved in the Lasem batik industry.

Based on the explanation, this article attempted to explore the life of Chinese entrepreneurs based on several questions. First, how were the social, cultural and economic dynamics in the Lasem batik industry, especially those belonging to Chinese entrepreneurs? Second, What was the resilience strategy used by Chinese entrepreneurs in facing changes in the Lasem batik industry. Socio-historical insights were used critically to project the dynamics of ownership and see the fate of Chinese entrepreneurs who were still involved in the Lasem batik industry. The social, cultural and economic dynamics have had a significant impact on all aspects of Chinese 
entrepreneurs, thus creating strategies and cultural resistance was essential to face social change.

\section{Method}

This study used a qualitative method with a narrative study approach in relation to its aim to understand the dynamic narrative of change for Chinese entrepreneurs in the Lasem batik industry. Creswell \& Poth (2017), stated that narrative studies tend to highlight individual experiences that were expressed in a chronological sequence of stories. The sequence of the various experiences presented by the informants was the primary basis for finding field data (Eichsteller, 2019). Therefore, the data collection technique was carried out through participatory observation and in-depth open interviews with informants. Researchers participated in various activities of the Lasem batik industry and interacted directly with Chinese entrepreneurs.

This research was conducted for two months using several village areas in Lasem District, Rembang Regency, Central Java as samples. The research focus was focused on four areas, namely Babagan Village, Dorokandang Village, Gedongmulyo Village, and Sumbergirang Village. The reasons for choosing the location were due to the historical background of the emergence of Lasem batik and the status of the area, which was established as a Lasem batik centre owned by Chinese entrepreneurs.

The selection of informants was carried out through a purposive technique which emphasized the need for data according to the focus of the study, namely the owners of the Lasem batik industry from the Chinese entrepreneur group. In addition, the criteria also refer to the historical background of the industry (having undergone several transitions for the next generation), traditional production modes, and the largest production scale in Lasem District, Rembang, Central Java. The number of informants in this study was six people, consisting of four male entrepreneurs and two female entrepreneurs. They were the owners of the Lasem batik industry from the Chinese group from the second to the third generation and native entrepreneurs who continued the continuity of the Lasem batik industry from 1950 to 1970 . The purpose of selecting these informants was to find out narratives related to the dynamics of changes in the Lasem batik industry from pre-reform to the present from the perspective of Chinese entrepreneurs.

\section{Results and Discussion}

\section{History of batik Lasem}

The existence of Lasem as a centre for batik production cannot be separated from the figure of Bi Nang Un, a ship captain who followed Admiral Cheng Ho from Yunnan (Utomo et al., 2018: 21-22). Stories and local records in Babad Lasem by $\mathrm{Pu}^{\prime}$ Santri Badra stated that Bi Nang Un asked permission from Pangeran Wijaya Badra to settle down and build Chinese community settlements in the northern coastal area which was now Lasem (Molen, 2017). After his application was approved, Bi Nang Un returned to China to pick up and bring his wife to live in Lasem (Setyoningrum et al., 2019: 175).

Bi Nang Un's wife, $\mathrm{Na} \mathrm{Li} \mathrm{Ni}$, actually has some artistic skills. During her stay in her new house, she introduced batik art techniques to local residents in Taman Banjaran Mlati, Kemandhung (see Atabik, 2016). Na Li Ni's 
batik skills were different from local batik because she uses a technique that was typical of her native region, namely by processing the cloth drawn before the traditional motif was drawn on it. This uniqueness became an attraction for Chinese traders who were domiciled in Lasem, so that batik, which was initially everyday clothing, turned into a trading commodity (Unjiya, 2014).

The astronomical demand for batik triggered the Chinese descendants in Lasem to establish a batik home industry. This phenomenon, at the same time, encouraged Lasem batik to be controlled by Chinese entrepreneurs. In addition to large capital factors and extensive social networks, control was also greatly influenced by the division of the class structure of society during the colonial period (Lindblad, 2007: 371-372). Chinese entrepreneurs exploited this advantage by using trains and road access to conduct trade so that Lasem batik became famous in the Java region. The industry was estimated to be able to produce $1,500-2,000$ pieces of cloth per year at that time (Kusnawan, 2011: 91).

The high production of batik made Lasem one of the six largest batik industrial centres during the Dutch colonial period. It competes with Surakarta, Yogyakarta, Pekalongan, Banyumas, and Cirebon (Muarifuddin, 2017). However, behind the success of Chinese entrepreneurs, there was an exploitation of batik makers (Sariyatun \& Padmo, 2002: 308-309). As a result, in 1931, the Dutch colonial government issued a summons as a strong reaction to the exploitation of labour. This incident sparked a dispute between Chinese entrepreneurs and the Dutch government. Finally, in 1750, the Dutch government lowered Lasem's status from a regency (regentschap) to a subdistrict (onderdistrict) and Rembang to a regency (Tjiook, 2017: 570).

During the Japanese occupation, Lasem's batik industry continued to decline until many were out of business. One of the causes occurred because of the repression through the death penalty against the Chinese community by the Japanese government (Kusnawan, 2011: 89). The Japanese saw the Chinese community as an enemy in cahoots with the Dutch. Japan made written regulations that prohibited the Chinese community from being involved in and controlling the Indonesian economy. The regulations and prohibitions from Japan caused chaos for the people; they experienced pressure and suffering, especially the Chinese community.

Entering the 1950s, the situation in the Lasem area began to be more conducive. This situation was exploited by Chinese entrepreneurs to rebuild businesses that had been hampered. One of the ways was through the development of business networks by utilizing the remaining venture capital to create new businesses in Lasem, which was marked by the emergence of new batik entrepreneurs. The transition carried out in the economic sector proved able to re-establish the position of the Chinese community to dominate the market economy in Lasem.

The cooperative relationship between the Chinese and Javanese people in the Lasem batik industry did not last long. This relationship was exacerbated by the issuance of "Government Regulation no. 10" in 1959 (PP 10/1959) which prohibited China from conducting trading activities in rural areas. The politicization of this policy led to the 
provision of capital for local residents to open batik businesses. Lasem residents took this opportunity to create many local batik industries. The emergence of the batik industry in the local community gradually reduced the batik production of Chinese entrepreneurs. Finally, more than half of the Chinese population in Lasem migrated to other big cities (Tjiook, 2017: 572).

\section{Cultural acculturation: Chinese and Javanese}

The interaction of cultural values between local people and immigrants from China was estimated to have reached its peak after the arrival of Admiral Cheng Ho's expedition in the 15th century. The distinction of cultural values and structures prompted Chinese people who came to Indonesia to mingle with local communities. Contextual differences led to identity transformation through the cultural identification of Indonesian society (Mao \& Shen, 2015: 1542). The value diffusion of Chinese society increased during the Dutch colonial period (1596-1942) because they became targets of violence (Turner \& Allen, 2007: 114). This was exacerbated by a series of national assimilation policies that took place from 1960 to 1970, which increasingly discriminated against the Chinese community in Indonesia (Mackie, 1999; Melissa, 2013).

This phenomenon is the background for the negotiation of values in Chinese society, for example, the adoption of Indonesian or Javanese names, wearing batik clothes, and showing interest in the local culture. All these efforts were made to overcome the social, cultural, and economic dynamics that occurred (Kristiono, 2018; Riyanti, 2013). A similar phenomenon also occurred in Lasem. The Chinese community maximized social relations so that the Lasem community could accept them. According to Jatmiko (2019), the harmonious relations of the local Lasem community are evident from several cultural artefacts, such as building architecture, household furniture, interior shapes, ceramic ornaments, and batik.

Lasem Batik is one of the acculturations passed down by the Chinese community
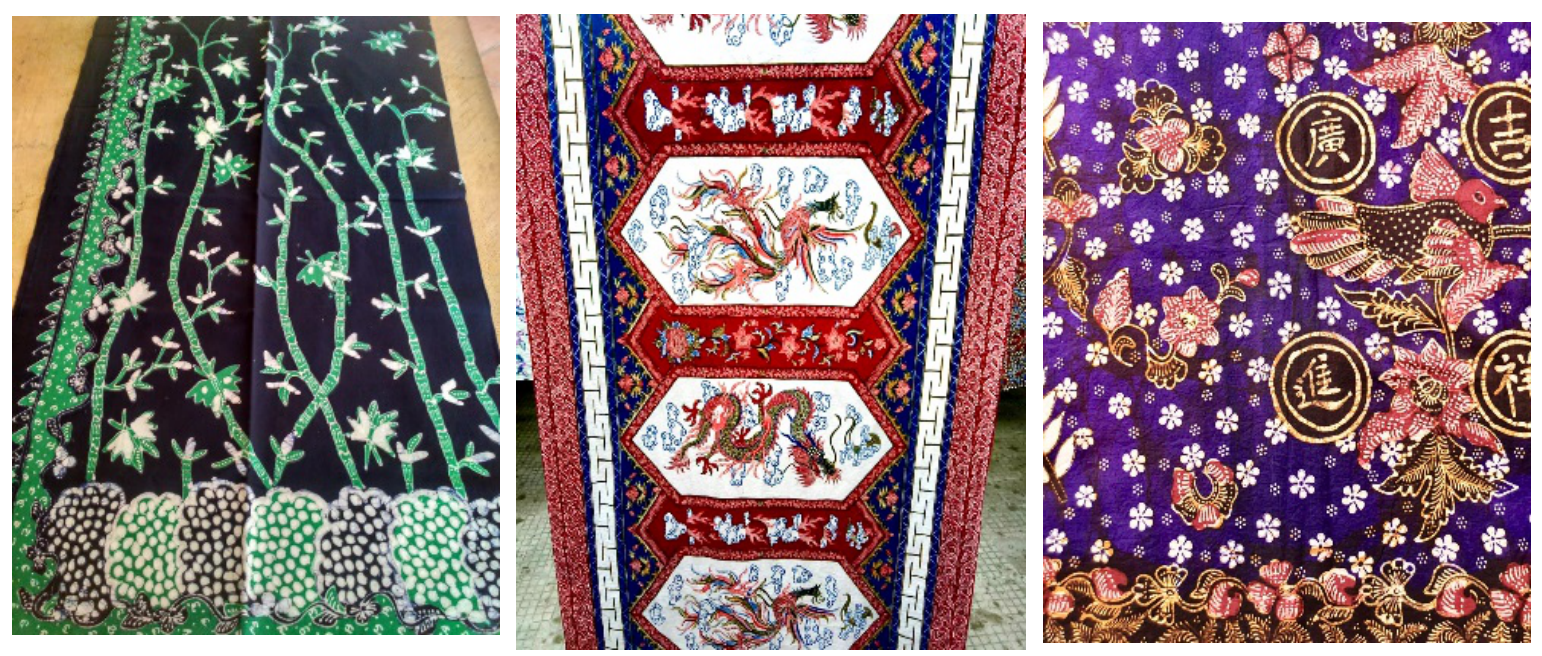

Figure 1. Acculturation in Lasem Batik

(Source: research documentation) 
and is a legacy that still exists today. Approximately 21 Lasem batik motifs have been certified by Intellectual Property Rights and are protected by the Copyright Law Number 19 of 2002 (Mastur \& Kotimah, 2019). However, batik art in Lasem is not only obtained from the Chinese community. Indonesian local communities, especially those in coastal areas, have previously been familiar with the art of batik using coconut leaf media with a variety of animal and plant motifs (Karsono \& Tulistyantoro, 2016: 201202).

The local community then developed acculturation of motifs, such as clouds, temples, puppets, and adhered to the philosophies of each region. Meanwhile, influences from the Chinese tradition offer more advanced batik techniques using Chinese motifs and red colours. The combination of these two batik elements is the basis for the emergence of batik art in the Lasem area. Figure 1 shows an example of Lasem's typical batik art.

The acculturation of cultural values, at first, was only intended to syncretize the culture of the Chinese community in facing differences with Javanese culture in Lasem (Utomo et al., 2018). However, along with changing social conditions with the increasing number of Lasem batik industry, acculturation has changed its meaning to become more complex. Chinese entrepreneurs acculturate batik motifs to maintain the continuity of batik production by attracting people's buying interest. One Chinese entrepreneur explained that Lasem batik variations with Javanese-Chinese motifs but still dominated by Javanese elements:

\begin{abstract}
"The motive that I am developing now tends to be elements of Javanese culture, only processing techniques that still maintain the old [Chinese] tradition. Sometimes, I make batik according to people's conditions. For example, during the harvest season, I make batik with elements of rice, grass, or plants. So batik must include elements of harvest culture. I also created a Chinese New Year culture. Actually, to attract customers, especially now that there are many new entrepreneurs [...] how do we combine two types of culture, Javanese-Chinese. Such a combination attracts buyers" (Interview with AL, 2019).
\end{abstract}

Chinese entrepreneurs deal with social changes in the function of value adaptation through acculturation of cultural values (Parsons, 1951); or even under certain conditions also do hybridization (Setyoningrum et al., 2019). Chinese entrepreneurs tried to make cross-cultural exchanges in the context of the diversity of cultural values. The phenomenon of 'cultural hybridity' conceptualizes a mixture of cultures resulting in a new identity in the negotiation process (see Bhabha, 1994; Shah, 2016). The third space (liminal) was used by Chinese entrepreneurs to articulate new potential socio-cultural meanings.

In this context, Chinese entrepreneurs developed a mixture of cultural symbols and reconstructed social identities to taint the boundaries of differences. The subjective transformation of Chinese entrepreneurs created a hybrid identity which was used as a means of survival in the Lasem batik industry. In addition to developing the sustainability of the batik industry, this strategy allowed Chinese entrepreneurs to coexist with local entrepreneurs. In addition, the acculturation strategy through the development of batik 
motifs is also influenced by adaptation to changes in consumers and marketing competition.

"For current motives, it is more modern. In the past, we tended to be classic [the result of acculturation], it was still original-for example, three states or other ancient types. However, now, we are changing to more attractive, dynamic, and varied motives that can be sold in the market" (Interview with GP, 2019).

Chinese entrepreneurs seem to have transcended the old cultural boundaries, which simultaneously enriched the cultural and economic level. Cultural heritage innovation in making Lasem batik motifs is enriched with new cultural values. The reproduction of the novelty of cultural symbols through acculturation is a complex dynamic process to gain opportunities for acceptance of a new identity. Moreover, it was used as a transitional process by Chinese entrepreneurs in overcoming economic obstacles in the condition of an ever-developing society.

Seeing this condition, Chinese entrepreneurs in Lasem encouraged a structural differentiation process. The differences in the characteristics of the local Lasem community and the Chinese community created a new sub-system that led to differentiation in group structures. Intergroup distinctions in society promote social change and development (see Parsons, 1951). In other words, structural differentiation creates a system that is more balanced and more advanced because there is an increase compared to before. This evolutionary cycle of change demands that the sub-structure performs adaptive renewal of social capacity in order to carry out its primary function.

\section{Batik as a legitimacy of Chinese community assets}

Lasem batik has initially been a symbol of cultural acculturation that has much history that characterizes the Chinese community in Lasem (Lukman et al., 2018; Maghfiroh et al., 2019). Upper-class people, both Javanese and Chinese, use batik for specific events. Some Chinese people also use batik cloth as daily clothes (Nurhajarini \& Purwaningsih, 2015; Unjiya, 2014). Upper-class people, both Javanese and Chinese, use batik for specific events. Some Chinese people also use batik as daily clothes:

\begin{abstract}
"According to history, it is said that Lasem batik was brought by Bi Nang Un when he lived in Lasem. Then, the descendants married Indonesians. Yes, Javanese. Hence, the Lasem batik motif is evidence of Javanese and Chinese culture, which are known as the three countries [...] Lasem batik is famous for its mixture of cultures and its red colour. Finally, traders from China, Holland, Japan or Java like Lasem batik. If I'm not mistaken, batik is used for traditional events, both family and sacred events. The development of Lasem batik started there as far as I know" (Interview with PW, 2019, 2019).
\end{abstract}

The tremendous economic opportunity for batik finally stimulated the Chinese community to build the Lasem batik industry. Lasem's batik orientation, which was previously a symbol of cultural acculturation, has turned into batik as an economic asset. At first, Lasem's batik business was initiated on a home business scale, but then it continued to develop into a large-scale business. Some batik entrepreneurs said that batik was only traded for the Chinese community to provide for basic needs. However, over time, the demand increased so that Chinese 
entrepreneurs dominated the circulation of the Lasem batik market:

\begin{abstract}
"Batik Lasem originally came from Chinese people who came to Lasem. This batik was originally made by Chinese people to fulfil their daily needs. Then, more and more interest. This batik advances the economy of the Lasem community because of its high price. The motive also has Chinese elements $[\ldots]$, so the Rembang community has also stated that Lasem batik is a product of Chinese culture" (Interview with JK, 2019).
\end{abstract}

In the period of the late 17th and early 18th centuries, there appears to be a process of acculturation and economic penetration of local markets in Java by the Chinese community (Carey, 1984). The business ties of Chinese entrepreneurs in the Lasem batik industry were carried out quickly because knowledge and management were passed down in one generation. The batik business is generally managed by family members up to several generations, either by immediate family or extended family. All business activities of the Chinese community are closed, so that non-family members are omitted (Kusumantoro et al., 2020; Sharma et al., 1997).

This fact shows the dominance of Chinese entrepreneurs in the batik business in Lasem. This situation is similar to the Keris batik industry in Surakarta, where peranakan Chinese families control industrial ownership by taking the stamped batik market around Surakarta (Carey, 1984). As a result, local people's access to directly involved in the management of the batik industry system is minimal. They only worked as batik labourers in Chinese entrepreneurs' houses.

However, around 1965, the repressive policies formulated by the New Order government cornered the Chinese community (Kristiono, 2018). In 1970, the entire business of the Chinese entrepreneurs' family began to disrupt, and the Lasem batik industry began to suffer losses. During the collapse of the Lasem batik industry, many Chinese entrepreneurs closed their industries and decided to move to other cities. This situation causes discontinuity of collective memory of Chinese batik entrepreneurs. This is consistent with the narrative of the following informants:

"So in the past, before Pak Soeharto, batik entrepreneurs were descended from Chinese families themselves. However, after many restrictions and obligations on releasing Chinese identity by the government, the batik business in Lasem began to decline. In the past, the house of the batik maker was nice and luxurious. Anyway, the batik house is extraordinary, and almost the same, the boss of the batik business must be rich and Chinese [...] then there was the reformation, and they went bankrupt, many of whom moved to Semarang, Surabaya, Jakarta. They chose to leave Lasem and look for other businesses. The batik business was finally quiet, and the ownership of Chinese entrepreneurs decreased a lot" (Interview with SH, 2019).

When the Lasem batik industry began to increase again, many new Chinese entrepreneurs had limited knowledge of the characteristics of Lasem batik. Some entrepreneurs then imitate batik designs from other regions to increase sales and enrich their motives. Without realizing it, this eliminates the originality of Lasem's batik (Setyoningrum et al., 2019: 176). At the same time, new Chinese entrepreneurs were also in trouble because Javanese entrepreneurs were acquiring the Lasem batik business. Many Javanese entrepreneurs 
have independently established Lasem's batik industry. Government support through training also encourages local communities who have the capital to build the Lasem batik industry:

"In the past, there were almost no batik craftsmen from Java. There are but few compared to China. However, after the reformation, the government even paid for anyone interested in participating in batik, making training and management training. From there, now many Lasem batik makers are of Javanese ethnicity [...] all of the craftsmen feel that they are decreasing, especially in the past when the Chinese were selling batik. There must be competition with Javanese batik makers. Moreover, the price is lower, and the models vary. This is different from the batik made by the Chinese, which maintains the traditional process. However, you can see the quality yourself" (Interview with SH, 2019).

Until now, the production of Lasem batik by the Javanese community has also been found in several villages in Rembang Regency. The impact was also felt by Chinese entrepreneurs whose control of the Lasem batik industry began to shift. In addition, the development of the Lasem batik industry as an economic asset also has the relevance of the contestation of cultural ownership between the Chinese group and the local community. This transition triggered Chinese entrepreneurs to make a mutual agreement, namely to mutually acknowledge that Lasem batik is a typical batik of Chinese culture because Chinese entrepreneurs initiated batik.

\section{Knitting hope: Forming the Lasem Batik Association}

During the early post-reform transition period in 1998-2000, there was a recession in the Lasem batik industry. After the 2000s, Lasem's batik business gradually improved with the opening of several industries owned by Javanese and Chinese entrepreneurs. The existence of Lasem batik is starting to be recognized by the local community and outside the Rembang Regency area. From 2009 until now, many new batik entrepreneurs have founded Lasem batik houses. The majority of this regeneration was followed by Javanese entrepreneurs who tried their luck in the Lasem batik industry. Meanwhile, several others are Chinese entrepreneurs who are dominated by the older generation who reopened the industry or, the younger generation who continue the batik business inherited from their family:

\begin{abstract}
"The Lasem Batik Industry experienced ups and downs. In the past, most of the entrepreneurs were Chinese. But now it is more populist. These Javanese entrepreneurs used to work at my place. Then they have a great interest in doing business. If they become labourers, the income is small, so they are interested in starting small businesses [...] so, back in the 2000s, it was a low period. The existing businesses are still few, and many are closed. The industry started booming in the 2009's. Some have opened production again, and some are descendants of their parents" (Interview with LK, 2019).
\end{abstract}

However, the emergence of new batik industries in Lasem did not bring about harmonious changes among batik entrepreneurs. Social jealousy in the batik trade triggers a very worrying sentiment. Local entrepreneurs are trying to take chances because, after the vacuum of Lasem batik, there is a high demand in the market. On the other hand, the marketing scope of Chinese entrepreneurs became limited, so that small and medium scale batik entrepreneurs 
depended on the market from intra-ethnic based personal networks (Koning, 2007: 151). As a result, the relationship between batik entrepreneurs has shown increasingly visible contestation and has led to divisions in the Lasem batik industry.

The confusing issue of segregation among Lasem batik entrepreneurs has prompted a reaction from the Rembang Regency government. Several regulations were formulated to resolve disputes and the government's efforts to revitalize Lasem batik. Finally, the Rembang Regency government made a written policy to support the sustainability of the Lasem batik industry. One of them is stated in the Rembang Regent Regulation No. 29 of 2017 concerning the Preservation of Lasem Hand-drawn batik. This initial realization aims to revive the Lasem batik industry by accommodating all batik industries or entrepreneurs. On the other hand, the government is increasingly aggressively promoting Lasem batik through educational facilities by including batik in the student curriculum (Farid, 2013):

\begin{abstract}
"Batik Lasem had experienced a drastic decline because there was no regeneration. The local government then held batik training and held batik competitions for students throughout Rembang Regency [...] some included batik learning curricula in schools, starting from elementary, junior high, high school, and even now some are starting to implement uniforms batik in schools" (Interview with JK, 2019).
\end{abstract}

All entrepreneurs gave positive appreciation to the local government for the introduction of Lasem batik. This success was responded to by the implementation of other policies, namely the integration process with the formation of the Batik Cluster and Batik Village associations (Muarifuddin, 2017;
Suparno et al., 2019). Its members consist of all Lasem batik entrepreneurs in Rembang Regency. It is hoped that the formation of the association and the batik village can improve relations between Lasem batik entrepreneurs in the Rembang area which were previously divided. Especially with the shared spirit that focuses on revitalizing Lasem's batik culture through the teaching network and the batik museum, this has something in common with Pekalongan (see Wang, 2019):

\begin{abstract}
"In the relationship between batik owners, now there is an association. The members were mixed, Javanese-Chinese mixed into one. I do not understand who the chairman is in this area. But, as far as I know, the Lasem batik association is chaired by Pak Santoso Pusaka Beruang. Otherwise, it might be Mrs Win or the one with Sumber Rejeki. Finally continued to intervene, no enmity or envy. For example, you are Chinese, and I am Javanese, no. Get along well, work together" (Interview with AL, 2019).
\end{abstract}

The interview bit shows that the association is useful for all Lasem batik entrepreneurs. Although chaired by an ethnic Chinese, social relations between entrepreneurs in the Lasem batik association run harmoniously and effectively in order to achieve common goals. The Lasem batik industrial network agglomeration can connect entrepreneurs with business partners in order to obtain the necessary resources, such as information, capital, and support from fellow entrepreneurs (George et al., 2001). Collaborative relationships through batik associations can at least create healthy competition between Lasem batik entrepreneurs from Java and China in gaining new market opportunities.

Even so, the association of entrepreneurs in the Lasem batik association does not 
always run well. The continuity of the Lasem batik association has gradually created losses for Chinese entrepreneurs. Several Chinese entrepreneurs stated that they experienced marketing problems because Javanese entrepreneurs hindered them. The popularity of Chinese entrepreneurs in Lasem batik became discredited. As a result, the hopes of Chinese entrepreneurs for profit turned into losses:

"At an exhibition, I was harmed by them. They use my brand in the market because buyers know my quality. Finally, many other seller friends left batik to be sold, while the size of the exhibition stand was only $3 x$ 3 meters. Some join [selling], and that is an obstacle for us. In the past, before I produced batik for my brand, I indeed brought some other friends' batik. But that was before 2010. After that, I did not want to bring it, let alone imitate quality so that it would sell well. I also have much batik, bringing their batik is useless. The price is too high, and the quality differs greatly. In fact, I was the one who suffered losses" (Interview with $\mathrm{SH}$, 2019).

Seeing this condition, integration through the batik association is expected to be able to maintain the value of adjustment to industrial changes. In fact, this does not create collectivism that maintains social order. More than that, the association has turned into a contestation of the interests of each batik entrepreneur. Competition among members of the Lasem batik association continues to increase the dynamics because conflicts between the two groups of entrepreneurs with class backgrounds will continue to occur (Winarnita et al., 2020). The problem is, these signs can already be seen from the increasing economic competition and expansion of the Chinese into several industries, such as sugar, cigarettes, and the batik industry which was previously the domain of Javanese and Arabs.

However, the competition in the Lasem batik association cannot be simplified into a mere economic problem but must be seen more deeply by looking at issues of identity and culture. Even though the Chinese in Indonesia have extraordinary heterogeneity, the stigma of society still categorizes them as outsiders. This perception is based on the lineage of non-Indonesian ancestry with geographic roots (Turner \& Allen, 2007: 114). Thus, the relationship between Javanese and Chinese entrepreneurs broadens the horizons of hybrid identity and culture. On the one hand, they both accept the mutual consensus, and vice versa, the two groups, are in a state of tension in the dimensions of identity and culture.

\section{The resilience of Chinese entrepreneurs in Lasem batik industry}

The resistance of Chinese entrepreneurs in facing the transition to ownership of the Lasem batik industry is definitive evidence of socio-cultural resilience. The significance of social processes that affect aspects of life cannot be addressed but must go through social resilience at the individual and group level (see Elias et al., 1997). In general, the concept of resilience provides a framework for understanding adaptation experiences in order to survive or recover from challenges that threaten its stability, survival, and development (Luthar, 2003; Masten, 2001; Walker et al., 2004).

All Chinese entrepreneurs who continued to exist turned out to have extraordinary resilience so that they could develop and survive in several political periods in Indonesia. Most informants reported that whenever they face socio- 
economic pressure, they try to survive by asking family members, neighbours and networks of friends for help. The sociocultural resilience adopted by Chinese entrepreneurs simultaneously changed the paradigm of inter-group relations. The two of them build dialogical relationships and make adaptations to face social change. According to Ungar and Liebenberg (2013), resilience is not only about individual resilience, but also negotiations between groups to help each other and improve welfare.

This opinion is not much different from the situation of Chinese entrepreneurs in the Lasem batik industry. They seek to increase resilience among local communities through various considerations. The factors inherent in Chinese entrepreneurs were continuously explored in order to have a significant impact on the construction of resilience. One of them can be done with a cultural function through the process of adjusting daily experiences with individuals, families and communities (Castro \& Murray, 2010: 375). In the context of Lasem batik industry, Chinese entrepreneurs tend to survive and maintain the continuity of the batik industry through the process of internalizing local culture (the function of cultural adaptation). All actions are cantered on the locality that highlights a common set of beliefs and values, such as language, assimilation, enculturation, and socialization (Castro \& Murray, 2010; Spence et al., 2016).

The social resilience of Chinese entrepreneurs is also carried out through two social functions, namely through social capital and hybridization. First, Chinese entrepreneurs build social capital collectivism through trust, authentication, and expansion of social networks to help the batik industry survive. This condition is in accordance with the opinion of Manyena and Gordon (2015) that social capital functions as an informal force owned by each individual to carry out resilience in society. The capacity of social capital can solicit social assistance in developing and maintaining the remaining Lasem batik businesses owned by Chinese entrepreneurs.

The synergy of all these elements becomes a trajectory of social capital that can ensure the successful resilience of Chinese entrepreneurs in the transition to ownership of the batik industry and can adapt to shortterm social changes. According to Castro \& Murray (2010: 386-388), pooling social and human capital can increase resilience capacity through resources that facilitate effective action. In other words, social capital has implications for developing resilience as a product of the interactive effect of individuals with the local environment.

The second is the hybridity function that produces hybrid identities for Chinese entrepreneurs in Lasem District. Chinese entrepreneurs tried to build socio-cultural resilience through subjective integration as local citizens and obscuring their Chinese identity. The process of integrating Chinese identity can be seen through the marriage relationship between Chinese entrepreneurs and batik workers, the majority of whom are local residents. The occurrence of an amalgamation process in Lasem then formed a new identity and language structure, namely as a Chinese-Javanese (wong Lasem, and Cina wurung Jawa urung) with a distinctive Laseman dialect. The construction of a new identity for Chinese entrepreneurs and the use of the Laseman language actually strengthened their resilience because they succeeded in obscuring their identity. However, hybridization must sacrifice its 
original identity to maintain socio-economic existence in the Lasem batik industry. This is in accordance with Richmond (2009) statement that hybridity becomes a subjective dialectic because it shows how to interact, fight, tolerate, and accept differences simultaneously.

However, more than that, the hybridization function of Chinese entrepreneurs shows a processual resilience of hybrid identities. The resilience of Chinese entrepreneurs throughidentity hybridization encourages the continuity of the adaptive cycle model. Holling and Gunderson (2002) state that social change enhances individual resilience efforts through several adaptive cycles in spatial and temporal dimensions. The dynamics of individual transformation proposes a panarchy model, which is an abstraction model of identity reconstruction through dynamic social processes and interrelated with other adaptive elements.

The panarchy model describes four phases, consisting of growth, accumulation, restructuring and renewal (see Allen et al., 2014; Endre, 2019; Rampp, 2019). he growth process occurs when individuals begin to exploit the structure, while the direction of its development still depends on the structure itself. For example, changes in Chinese entrepreneurs who tried to slowly remove the original structure (not entirely), but still maintain their previous identity. Second, the accumulation phase which describes the conservation process in an efficiently connected state so that the process is stagnant and vulnerable. It happened when Chinese entrepreneurs integrated themselves with the local community, including doing amalgamation to construct hybrid identities.

The process of resilience in the identity of Chinese entrepreneurs increases when it reaches the restructuring phase because it represents the process of releasing identity in facing the critical point of an individual. At this time, Chinese entrepreneurs assembled the novelty of their social identity as a Lasem community, although physically they were still considered Chinese. In the last phase, there is renewal through continuity of adaptive arrangements and building continuity of transformed identities. This refers to the adaptive nature of Chinese entrepreneurs who can maintain ownership of the Lasem batik industry, especially entrepreneurs who have survived several generations and socio-political periods. Thus, the transformation of Chinese entrepreneurs in the Lasem batik industry has resulted in socio-cultural resilience as a resilient response to the dynamics of social change. Cultural resilience is applied by Chinese entrepreneurs in the production of Lasem batik. Conversely, social resilience is manifested in a subjective order in the form of a processual hybridity resilience model or transformative autogenesis (Rampp, 2019: 67).

\section{Conclusion}

This article has explored in depth the process of change and the resilience of Chinese entrepreneurs to remain in the Lasem batik business. In principle, the transition of ownership of the batik industry from Chinese entrepreneurs to Javanese entrepreneurs was caused by the pressure of the ruling political situation. However, with the times, Chinese entrepreneurs in Lasem felt that local dynamics actually drove the complexity of social change. The socio-economic vulnerability of Chinese entrepreneurs in the batik industry has 
forced them to be resistant to prolonged challenges, thus offering several strategies of resilience.

The socio-cultural adaptation trajectory, in a sustainable manner, involves Chinese entrepreneurs to survive and maintain the continuity of the industry. Initially, all entrepreneurs depended on individual capabilities, such as batik motif authentication, acculturation, and assimilation. However, the resilience conceptualized by Chinese entrepreneurs only resulted in short-term adaptive gains. Seeing the increasingly complex conditions, Chinese entrepreneurs then set resilience to the subjective domain. In this position, change is interpreted by Chinese entrepreneurs as a way of understanding the dialectic of external structures and efforts to remain resistant.

We argue that the socio-cultural resilience of Chinese entrepreneurs in the batik industry tends to refer to two linear processes, namely the use of social capital and the hybridization of identity. Social capital has limitations because the strength of micro-social cohesion in communal relations significantly contributes to exclusive forms and has the potential to become an intergroup conflict. This obstacle is addressed by means of identity hybridization. Chinese entrepreneurs try to build a hybrid identity processual in order to integrate themselves and unite the identity segments according to the dynamics in society. The reductionist projection of the hybridization of processual identities played a valuable role, not only in the resilience of Chinese entrepreneurs but also in capturing the simultaneous fragmentation and adaptation of various connected local social structures. Thus, socio-cultural resilience provides a heuristic projection in explaining strategies in the adaptive cycle of Chinese entrepreneurs. The resilience approach implemented by Chinese entrepreneurs in the Lasem batik industry accommodates multiple characteristics, ranging from structural degradation and identity transformation. In this way, sociocultural resilience makes it possible to offer a perspective beyond the established static system. Instead of considering the dynamics in society, furthermore, the resilience of Chinese entrepreneurs provides a processual linear trajectory, namely through tensional processes along with the presence of contextual and situational vulnerability challenges.

\section{Declaration of Ownership}

This article is our original work.

\section{Conflict of Interest}

There is no conflict of interest to declare in this article.

\section{Ethical Clearance}

This study was approved by the institution.

\section{References}

Allen, C. R., Angeler, D. G., Garmestani, A. S., Gunderson, L. H., \& Holling, C. S. (2014). Panarchy: Theory and application. Ecosystems, 17(4), 578-589. https://doi. org/10.1007/s10021-013-9744-2

Atabik, A. (2016). Percampuran budaya Jawa dan Cina: Harmoni dan toleransi beragama masyarakat Lasem. Sabda: Jurnal Kajian Kebudayaan, 11(1), 1-11. https://doi.org/10.14710/sabda. v11i1.13215 
Bhabha, H. K. (1994). The location of culture. Routledge.

Carey, P. (1984). Changing Javanese perceptions of the Chinese communities in Central Java, 1755-1825. Indonesia, 37, 1-47. https://doi.org/10.2307/3350933

Castro, F. G., \& Murray, K. E. (2010). Cultural adaptation and resilience: Controversies, issues, and emerging models. In J. W. Reich, A. J. Zautra, \& J. S. Hall (Ed.), Handbook of adult resilience. (hal. 375-403). The Guilford Press.

Creswell, J. W., \& Poth, C. N. (2017). Qualitative inquiry and research design: Choosing among five approaches. SAGE Publications Inc.

Eichsteller, M. (2019). There is more than one way: A study of mixed analytical methods in biographical narrative research. Contemporary Social Science, 14(3-4), 447-462. https://doi.org/10.1080 /21582041.2017.1417626

Elias, N., van Krieken, R., \& Dunning, E. (1997). Towards a theory of social processes: a translation. The British Journal of Sociology, 48(3), 355. https://doi. org/10.2307/591136

Endre, M. (2019). The Socio-historical constructiveness of resilience. In $\mathrm{B}$. Rampp, M. Endreß, \& M. Naumann (Ed.), Resilience in social, cultural and political spheres (hal. 41-58). Springer Fachmedien Wiesbaden. https://doi. org/10.1007/978-3-658-15329-8_3

Farid, M. N. (2013). Peranan muatan lokal materi batik tulis Lasem sebagai bentuk pelestarian budaya lokal. Komunitas: International Journal of Indonesian Society and Culture, 4(1), 90-121. https://doi. org/10.15294/komunitas.v4i1.2400

George, G., Robley Wood, D., \& Khan, R. (2001). Networking strategy of boards: Implications for small and medium-sized enterprises. Entrepreneurship \& Regional
Development, 13(3), 269-285. https://doi. org/10.1080/08985620110058115

Holling, C. S., \& Gunderson, L. H. (2002). Resilience and adaptive cycles. In L. H. Gunderson \& C. S. Holling (Ed.), Panarchy: Understanding transformation in human and natural systems (hal. 25-62). Island Press.

Jatmiko, M. I. (2019). Hibridisasi masyarakat Tionghoa di Kecamatan Lasem pascareformasi. Umbara: Indonesian Journal of Anthropology, 4(2), 101-114. https://doi. org/10.24198/umbara.v4i2.21697

Karsono, O. M. F., \& Tulistyantoro, L. (2016). Acculturation Chinese symbol on Madura batik motif. Asian Social Science, 12(4), 200-221. https://doi.org/10.5539/ ass.v12n4p200

Koning, J. (2007). Chineseness and Chinese Indonesian business practices: A generational and discursive enquiry. East Asia, 24(2), 129-152. https://doi. org/10.1007/s12140-007-9011-2

Krisnawati, E., Sunarni, N., Indrayani, L. M., Sofyan, A. N., \& Nur, T. (2019). Identity exhibition in batik motifs of Ebeg and Pataruman. SAGE Open, 9(2), 2158244019846686. https://doi. org/10.1177/2158244019846686

Kristiono, M. J.(2018). Dari Tionghoa ke Tjina: Telaah sejarah terhadap demonisasi etnis Tionghoa di Indonesia. Verity: Jurnal Ilmiah Hubungan Internasional (International Relations Journal), 10(19), 34-48. https://doi.org/10.19166/verity. v10i19.1309

Kurnia, E. D., \& Windarti, N. K. (2019). Local wisdom in the expression of the written batik lexicon in Lasem (ethnolinguistic study). Proceedings of the Fifth Prasasti International Seminar on Linguistics (PRASASTI 2019), 150-154. https://doi. org/10.2991/prasasti-19.2019.24 
Kusnawan, M. A. (2011). Perekonomian etnis Tionghoa di Kota Lasem tahun 1940-1950. Universitas Negeri Semarang.

Kusumantoro, Suman, A., Umi Mintarti Widjaja, S., \& Wahyono, H. (2020). Succession process in the family business: A Case study of Pekalonganese batik cloth enterprises, Indonesia. Humanities $\mathcal{E}$ Social Sciences Reviews, 8(2), 142-148. https://doi.org/10.18510/hssr.2020.8217

Lindblad, J. T. (2007). Indonesia and China today: New challenges with a long history. Journal of Developing Societies, 23(3), 369-392. https://doi. org/10.1177/0169796X0702300304

Lukman, C. C., Setyoningrum, Y., \& Rismantojo, S. (2018). Indonesian Chinese visual language of 'qilin' on Lasem batik altar cloth (Tok Wi). Journal of Arts and Humanities, 7(9), 84-94. https:// doi.org/10.18533/journal.v7i9.1488

Lukman, C. C., Setyoningrum, Y., \& Rismantojo, S. (2019). Revealing the intangible values in Lasem batik motif. Journal of Arts and Humanities, 8(9), 64-72. https://doi.org/10.18533/journal. v8i9.1728

Luthar, S.S. (2003). Resilience and vulnerability: Adaptation in the context of childhood adversities. Cambridge University Press.

Mackie, J. (1999). Tackling the "Chinese Problem." In G. Forrester (Ed.), PostSoeharto Indonesia: Renewal or chaos (hal. 187-197). KITLV Press.

Maghfiroh, Q., Kurniadi, E., \& Mulyanto. (2019). Write batik form of Krecak motif in the batik tulis Lasem Sekar Kencana company in Babagan Village, Lasem District, Rembang District. International Journal of Advanced Multidisciplinary Scientific Research, 2(2), 41-54. https://doi. org/10.31426/ijamsr.2019.2.2.1214

Manyena, B., \& Gordon, S. (2015). Resilience, panarchy and customary structures in afghanistan. Resilience, 3(1), 72-86. https://doi.org/10.1080/21693293.2014.99 2254

Mao, J., \& Shen, Y. (2015). Cultural identity change in expatriates: A Social network perspective. Human Relations, 68(10), 1533-1556. https://doi. org/10.1177/0018726714561699

Masten, A. S. (2001). Ordinary magic: Resilience processes in development. American Psychologist, 56(3), 227$238 . \quad$ https://doi.org/10.1037/0003066X.56.3.227

Mastur, \& Kotimah, S. (2019). Perlindungan hak cipta motif batik Lasem dalam Undang-Undang Nomor 28 Tahun 2014. QISTIE: Jurnal Ilmu Hukum, 12(2), 150-165. https://doi.org/http://dx.doi. org/10.31942/jqi.v12i2.3134

Maulany, N. N., \& Masruroh, N. N. (2017). Kebangkitan industri batik Lasem di awal abad XXI. Putrawidya, 18(1), 1-12.

Melissa, E. (2013). Representasi warga Tionghoa dan Kecinaan dalam media kontemporer Indonesia. Jurnal Komunikasi Indonesia, 2(1), 15-22. https:// doi.org/10.7454/jki.v2i1.7826

Molen, W. Van der. (2017). Sajarah Cina: A nineteenth-century apology in Javanese. Wacana, 18(2), 402. https://doi. org/10.17510/wacana.v18i2.590

Muarifuddin, M. (2017). Implementasi pembangunan desa wisata batik desa Babagan Kecamatan Lasem Kabupaten Rembang. Jurnal Pendidikan dan Pemberdayaan Masyarakat, 4(1), 51-70. https://doi.org/10.21831/jppm.v4i1.12713

Nurhajarini, D. R., \& Purwaningsih, E. (2015). Akulturasi lintas zaman di Lasem: Perspektif sejarah dan budaya (kurun niaga sekarang). Balai Pelestarian Nilai Budaya.

Parsons, T. (1951). The social system. Free Press.

Rampp, B. (2019). The question of 'identity' in resilience research. Considerations 
from a sociological point of view. In $\mathrm{B}$. Rampp, M. Endreß, \& M. Naumann (Ed.), Resilience in social, cultural and political spheres (hal. 59-76). Springer Fachmedien Wiesbaden. https://doi. org/10.1007/978-3-658-15329-8_4

Richmond, O. P. (2009). Becoming liberal, unbecoming liberalism: LiberalLocal hybridity via the everyday as a response to the paradoxes of liberal peacebuilding. Journal of Intervention and Statebuilding, 3(3), 324-344. https://doi. org/10.1080/17502970903086719

Riyanti, P. (2013). Relasi sosial pedagang Etnis Cina dan Etnis Jawa di pasar tradisional. Komunitas: International Journal of Indonesian Society and Culture, 5(1), 53-63. https://doi.org/10.15294/ komunitas.v5i1.2373

Sariyatun, \& Padmo, S. (2002). Usaha batik masyarakat Cina di Surakarta pada tahun 1900-1930. Sosiohumanika, 15(2), 301-316. https://doi.org/10.2121/ sosiohumanika.v1i1.20

Setyoningrum, Y., Lukman, C. C., \& Rismantojo, S. (2019). Visual style of 21 Intelectual Property Right (IPR) certified Lasem batik motifs as the expression of cultural hybridity. Humaniora, 10(3), 175. https://doi.org/10.21512/humaniora. v10i3.5680

Shah, D. M. (2016). Cultural hybridity: A postcolonial concept. Smart Moves Journal IJELLH, 4(12), 7. https://doi.org/10.24113/ ijellh.v4i12.1783

Sharma, P., Chrisman, J. J., \& Chua, J. H. (1997). Strategic management of the family business: Past research and future challenges. Family Business Review, 10(1), 1-35. $\quad$ https://doi.org/10.1111/j.17416248.1997.00001.x

Spence, N.D., Wells, S., Graham, K., \& George, J. (2016). Racial discrimination, cultural resilience, and stress. The Canadian Journal of Psychiatry, 61(5), 298-307. https://doi. org/10.1177/0706743716638653

Suparno, S., Wibowo, A., Mukhtar, S., Narmaditya, B. S., \& Sinta, H. D. (2019). The determinant factors of development batik cluster business: Lesson from Pekalongan, Indonesia. The Journal of Asian Finance, Economics and Business, 6(4), 227-233. https://doi.org/10.13106/ jafeb.2019.vol6.no4.227

Tjiook, W. (2017). Pecinan as an inspiration the contribution of Chinese Indonesian architecture to an urban environment. Wacana, 18(2), 556. https://doi. org/10.17510/wacana.v18i2.596

Turner, S., \& Allen, P. (2007). Chinese Indonesians in a rapidly changing nation: pressures of ethnicity and identity. Asia Pacific Viewpoint, 48(1), 112-127. https:// doi.org/10.1111/j.1467-8373.2007.00334.x

Ungar, M., \& Liebenberg, L. (2013). Ethnocultural factors, resilience, and school engagement. School Psychology International, 34(5), 514-526. https://doi. org/10.1177/0143034312472761

Unjiya, M.A. (2014). Lasem negeri Dampoawang sejarah yang terlupakan. Salma Idea.

Utomo, A. A. P., Joebagio, H., \& Djono, D. (2018). The batik Latoh as the result of maritime culture of Lasem community. International Journal of Multicultural and Multireligious Understanding, 5(3), 19. https://doi.org/10.18415/ijmmu.v5i3.136

Walker, B., Holling, C. S., Carpenter, S. R., \& Kinzig, A. P. (2004). Resilience, adaptability and transformability in social-ecological systems. Ecology and Society, 9(2), art5. https://doi.org/10.5751/ ES-00650-090205

Wang, C. (2019). Building a network for preserving intangible cultural heritage through education: A study of Indonesian batik. International Journal of Art $\mathcal{E}$ Design Education, 38(2), 398-415. https://doi. org/10.1111/jade.12200 
Winarnita, M., Chan, C., \& Butt, L. (2020). Narratives of exile twenty years on: longterm impacts of Indonesia's 1998 violence on transnational Chinese-Indonesian women. Identities, 27(2), 191-209. https:// doi.org/10.1080/1070289X.2018.1537639 